\title{
Debugging systematic bacteriology
}

THE International Committee on Systematic Bacteriology (ICSB) has reason to be pleased with itself. For there is shortly to appear in the International Journal of Systematic Bacteriology the ICSB's new Approved List of Bacterial Names, a list that will include only about 2500 of the 30,000 bacterial species that have been named over the years. Only a handful of those species that have been excluded are likely to worm their way back onto the approved list since, by the standards laid down by the ICSB, their alleged identity is unacceptable.

The identification of bacteria dates back, in principle, to 1753 and the Species Plantarum of Linnaeus although in practise it was only from the middle of the nineteenth century that identification of species started in earnest. The problem that has grown ever since then is that by modern standards the vast majority of named species were given descriptions that were totally inadequate for them ever to be recognised again. Furthermore, for very few of the 30,000 alleged species was there a type culture - that is, an authentic specimen of the original beast - with which any new specimen could be compared.

In these circumstances it had become almost impossible for anyone to identify, unambiguously, a new species of bacterium. To do so meant laboriously consulting old and inadequate literature. It meant sifting through hundreds of names, scores of which might apply to the same species. Experts would disagree about which names applied to the same species and which single name to opt for. The competing names often lingered on in the literature with each in turn being overturned or revived as new evidence turned up. And when the issue might have been settled by re-examining the species themselves, cultures either did not exist, were of dubious authenticity or had clearly become outgrown by contaminating bacteria.

It was because of this situation that the International Committee on Systematic Bacteriology of the International Association of Microbiological Societies was persuaded to undertake the formidable task of hacking away the dying, decaying and merely dubious foliage in the hopeless jungle of bacterial nomenclature. After years of committee work, the experts have decided that there are only about 2500 species of bacteria that are currently recognised by most bacteriologists and which possess type strains or equivalent type material. From now on bacteriologists need only consider these approved species and, of course, any that are subsequently added to it. Additions will be carefully controlled by the requirement for better descriptions and designations of type strains than in the past. More controversially, new names will only be acceptable once they have been published in the International Journal of Systematic Bacteriology

Had the last requirement amounted to a monopoly of publication there would have been room to criticise it both on principle and as a workable proposition. The committee, however, have acknowledged that publication of the full details of newly named bacteria can be in any scientific journal or book whilst stating that they will not validate any name until it has been announced (with reference to the full paper) in the International Journal of Systematic Bacteriology. This makes good sense since it will mean that any initial search through past names can henceforth be made in a single journal.

It is also good that the Judicial Commission of the ICSB is willing to consider proposals to re-admit bacteria that have been excluded from the approved list. No gathering of experts, however conscientious, could have hoped to make all the correct decisions and doubtless a small number of old names will get back on the list. The Judicial Commission should be firm but sympathetic to anyone who is willing to champion the re-appraisal of their pet species provided that they are prepared to produce adequate evidence, a modern description and a satisfactory type strain.

This attempt of bacteriologists to put their house in order has implications for other biologists. The great conservatism of nomenclaturalists is well known. The idea of abandoning the principles of priority is anathema to them. But when the application of the principle causes more instability than the stability it is intended to preserve, then it is indeed time to make a fresh start. The plan adopted for bacteria may be directly applicable to only a few other groups of living organisms. But the principles followed in the plan may be of wider use when the nomenclature of other groups of living creatures, or of other scientific entities (eg genes, enzymes, ecosystems) comes to need revision.

\section{New UK Select Committee needs more attack}

ONE of the first trials of the new UK select committee system took place last week, when the House of Commons Select Committee on Energy confronted the Secretary of State for Energy, $\mathrm{Mr}$ David Howell, and his junior ministers, on the government's recently announced nuclear policy. The Secretary of State undoubtedly won the battle.

Not that that was entirely due to the integrity of Mr Howell's case. While Mr Howell is a thoughtful minister, and well-briefed by his large department, there are inevitably weak points in his thinking and lacunae in his policy; and it is the job of the Select Committee to bring them out.

For example, what of the accusation that if the $£ 10-12$ billion of government money allocated to the nuclear plan had instead been allocated to existing and proven conservation technologies, three times the primary energy value of the reactors could have been saved? On a recent television programme, Mr Norman Lamot, the minister responsible for nuclear affairs, answered this with a remark about it being impossible to control the needs and desires of energy consumers, missing the point completely that both the nuclear plan and a conservation plan are matters of direct government spending, as when the gas-cookers of Britain were converted, at government expense, to North Sea gas.

Further, it is clear that one of the principle objectives of ordering ten new nuclear reactors is to assure the strength of the Biritish nuclear industry. But after the long history of set-back with the advanced gas-cooled reactor, and the loss of many highly-trained staff, is the industry capable of carrying the orders out?

The new arrangement of select committees, which parallels the arrangement of government departments and has hence eliminated the useful form of the Select Committee on Science and Technology, was intended to give MPs a more direct basis of attack on government policy. But on last week's performance it seems unlikely to have that effect. More of those serving on the committees should be prepared to do some hard homework, and the committees should be more prepared to organise themselves to attack and expose the weak points in government thinking. Neither the homework (except in one notable case) nor the organisation were particularly evident at the Select Committee on Energy last week. 